\title{
The multiplier effects of the Finnish sugar sector
}

\author{
Ellen Huan-Niemi ${ }^{1} \&$ Marja Knuuttila ${ }^{2}$ \\ ${ }^{1}$ MTT Taloustutkimus, Latokartanonkaari 9,00790 Helsinki, ellen.huan-niemi@mtt.fi \\ ${ }^{2}$ MTT Taloustutkimus, Lönnrotinkatu 5, 50100 Mikkeli, marja.knuuttila@mtt.fi
}

\begin{abstract}
Background information on the economic role of industries is crucial to policy and decision makers due to the involvement of public financing. At the provincial and municipal level, the economic role of industries is crucial for employment and tax revenues that sustain the livelihood of the provinces and municipalities in Finland.

This study employed an input-output model (IO model) to answer the question on the linkages between the sugar sector with the different industries in the economy and how much production, value-added and employment would be lost if the sugar sector in Finland would disappear totally. The IO-model would produce the direct, indirect and induced economic effects usually referred to as the multiplier effects of the sugar sector.

The gross output of sugar beet production is approximated at about $€ 33$ million, and the valueadded sugar beet production is estimated at $€ 17.2$ million. The output of the sugar factories is approximated to be $€ 165.7$ million, and the value-added is estimated at $€ 39.6$ million. Even though the effects of primary sugar beet production and sugar factory production including multiplier effects seem rather small compared to the total effects at the regional level, the actual effects are felt at the municipalities level in the form of decreasing tax revenues and unemployment if the sugar sector in Finland disappears and is not substituted for by other forms of production and industry.

The output effects of the sugar chain production including sugar beet production, sugar factories and sugar utilizing industries totals $€ 14371.0$ million when indirect multiplier effects $€ 8258.3$ million in addition to direct effects $€ 6112.7$ million are taken into account. The value-added effects of the sugar chain production totals $€ 4451.5$ million when indirect value-added effects $€ 2857.7$ million in addition to direct value-added effects $€ 1593.8$ are taken into account. The employment effects of the sugar chain production totals 58733 persons as the indirect employment effects 37979 persons in addition to direct effects 20754 persons are taken into account. As far as employment effects are concerned, the number of employees does not refer to full-time employees, but included also all those who are involved at any stages of the sugar chain production. The indirect effects include multiplier effects due to both household spending and intermediate input purchases. Hence, if the sugar utilizing industries are included in the production chain, the multiplier effects are considerable.

There is data to prove that without domestic production, the sugar price is higher for Ireland compared to the other EU member states due to imperfections in the EU sugar market after the reform of the EU sugar regime in 2006. The sugar price for consumers in Ireland is the highest compared to the United Kingdom (UK), Finland and Germany. The UK and Finland are not self-sufficient in producing sugar for the domestic market, but Germany has been always producing over its selfsufficiency limit. Therefore, the consumers in Germany enjoy the lowest price for sugar compared to Ireland, Finland and the UK. Due to the existing domestic sugar production in Finland and the UK, the price of sugar is lower in these countries compared to Ireland.
\end{abstract}

\section{Keywords}

sugar sector, multiplier effects, sugar utilizing industry, input-output model, domestic production 


\section{Introduction}

Sugar beet grown in Finland was only 11500 hectares in 2012 compared to 15 years ago whereby the area cultivated was at its peak with almost 35000 hectares. The number of sugar beet growers has plummeted to less than 800 compared to more than 30000 in the early 1960s. The importance of the sugar beet sector in Finland has evolved through the decades, and the number of sugar beet processing factories has dwindled down to only one in Säkylä. The sugar industry in Finland started soon after the First World War due to the acute lack of sugar and high price for sugar. Hence, the sugar beet processing factory in Salo was established in 1919. However, this factory was finally closed down following the reform of the EU sugar regime in 2006. The extreme weather conditions in Finland make sugar beet cultivation challenging, hence Finland has one of the lowest yields for sugar and beets compared to other EU member states. The most competitive producing areas in the EU are France, Germany, the United Kingdom and Poland, where the climate is more suited to growing sugar beet. Nonetheless, domestic sugar production in Finland plays quite an important role in the regions of Varsinais-Suomi and Satakunta because of the direct and indirect effects of the sugar beet production and processing to the local economy. This study employed an input-output model (IO model) to answer the question on the linkages between the sugar sector with the different industries in the economy and how much production, value-added and employment would be lost if the sugar sector in Finland would disappear totally. The IO-model would produce the direct, indirect and induced economic effects usually referred to as the multiplier effects of the sugar sector.

\section{Methodology}

The economic effects of the Finnish sugar sector are studied in a traditional input-output framework (Knuuttila and Vatanen 2008). This means that in addition to the direct effects of the sugar sector, the indirect effects on other industries are considered both at the national and regional level. It should be noted however, that even though we can construct an IO-model in a proper theoretical framework, data availability sets the limitations to the empirical estimation due to cost, time, accessibility etc. In this paper, the sugar sector direct effects including sugar beet production, sugar factories production and production of sugar utilizing processed products are derived from the national level. At the regional level, a case study on NUTS3 of Varsinais-Suomi includes indirect effects of primary sugar beet production and a case study on NUTS3 region of Satakunta also includes the indirect effects of the sugar factory production in Säkylä. Indirect effects include economic effects due to input purchases and household spending.

Results of the IO-models are categorized as direct, indirect and induced effects and they are usually referred to as multiplier effects of the industry studied.

Direct effects refer to the industry itself i.e. output and value-added generated and persons employed in the industry studied. In case of the Finnish sugar sector direct economic effects would refer to the effects of sugar beet production, effects of sugar processing and refining factories, and effects of production of sugar utilizing products.

Indirect economic effects answer the question how much output, value-added and employment is needed in other industries of the economy in order to generate the output of that particular industry studied. As such indirect effects refer to inputs purchased from other industries of the economy. Multiplier effects are here used as a synonym for indirect economic effects.

In case of the Finnish sugar sector indirect effects include inputs purchased in sugar beet production and inputs acquired at sugar factories. Inputs purchased in sugar beet production basically include seed, fuel and motor oils, chemicals like fertilizers and plant protectants, agricultural equipments and their trade, transportation and haulage. Input purchases at sugar factories basically include wide variety of materials, equipment and services (electricity, water, sewage etc.) in addition to the main raw materials for the sugar beet farms. This kind of inputs usually consumed during one growing season or production period are in national accounting called intermediates.

Induced economic effects in IO-literature refer to multiplier effects (output, value-added and employment) generated by households in spending the income earned in production. In the case of the Finnish sugar sector, this would include household spending of sugar beet production, sugar factories 
as well as the production of all local input suppliers. Induced effects also include effects generated by the industry studied when purchasing investment goods. The latter one however is empirically rarely done.

Theoretical framework for the input-output model economic effects estimation.

\begin{tabular}{|c|c|c|}
\hline$\underline{\text { Direct effects }}$ & $\underline{\text { Direct effects }}$ & $\underline{\text { Direct effects }}$ \\
\hline $\begin{array}{l}\text { Sugar beet production }+ \\
\text { products }+\end{array}$ & Sugar factories + & Production \\
\hline Indirect effects: & Indirect effects: & Indirect effects: \\
\hline$\leftarrow$ Inputs (intermediates) purchased & $\leftarrow$ Inputs purchased & $\leftarrow$ Inputs purchased \\
\hline$\leftarrow$ Investment inputs purchased & $\leftarrow$ Investment inputs purchased & $\leftarrow$ Investment inputs purchased \\
\hline$\leftarrow$ Household purchases & $\leftarrow$ Household purchases & $\leftarrow$ Household purchases \\
\hline
\end{tabular}

\section{Data}

Statistic Finland (2013a,b,c,d) provides official industry by industry economic data in form of national accounting. Single industries are classified by the Standard Industrial Classification (SIC). In national accounting, the economic role of individual industries is expressed in terms of output (value of gross production), gross domestic product (GDP) generated by individual industries' value-added and employment. Whereas in bookkeeping data for example, the Farm Accountancy Data Network of MTT Agrifood Research Finland provides the profitability calculation for farms (Taloustohtori 2013). Figures for the indirect economic effects of the sugar sector are derived from public sources. The estimated regional indirect economic effects of the sugar sector for NUTS3 Varsinais-Suomi and NUTS3 Satakunta are based on Statistic Finland (2006) regional input-output tables

\section{Results}

\section{Sugar beet production}

The direct effects of sugar beet production on output, value-added and employment in the national economy ( $€$ million, persons) and the share of the national aggregate agricultural production (SIC01 Crop and animal production).

\begin{tabular}{|l|l|l|l|}
\hline & $\begin{array}{l}\text { Output } \\
€ \text { million }\end{array}$ & $\begin{array}{l}\text { Value-added } \\
€ \text { million }\end{array}$ & $\begin{array}{l}\text { Employment } \\
\text { persons }\end{array}$ \\
\hline Sugar beet production & 33 & 17.2 & 800 \\
\hline $\begin{array}{l}\% \text { of aggregate agricultural production } \\
\text { (SIC01 Crop and animal production) }\end{array}$ & $0.5 \%$ & $0.5 \%$ & 0.8 \\
\hline
\end{tabular}

\section{Sugar factories (Säkylä \& Kantvik)}

The direct effects of production from sugar factories on output, value-added and employment in the national economy ( $€$ million, persons) and the share from the national food production aggregate (SIC10_12 Manufacture of food products etc.). 


\begin{tabular}{|l|l|l|c|}
\hline & $\begin{array}{l}\text { Output } \\
€ \text { million }\end{array}$ & $\begin{array}{l}\text { Value-added } \\
€ \text { million }\end{array}$ & $\begin{array}{c}\text { Employment } \\
\text { persons }\end{array}$ \\
\hline Sugar factories (Säkylä, Kantvik) & 165.7 & 39.6 & 285 \\
\hline $\begin{array}{l}\% \text { of the aggregate food industry output } \\
\text { (SIC10_12 Manufacture of food products etc.) }\end{array}$ & $1.5 \%$ & $1.5 \%$ & $0.7 \%$ \\
\hline
\end{tabular}

\section{Sugar utilizing food and beverage industry}

The direct effects of production from sugar utilising industries on output, value-added and employment in the national economy ( $€$ million, persons) and the share from the national food industry aggregate (SIC10_12 Manufacture of food products etc), manufacturing production aggregate (SIC_C Manufacturing), and national production aggregate (SIC_0 Industries total) (\%) in 2010 (Statistic Finland 2013c).

\begin{tabular}{|l|l|l|l|}
\hline SIC-industry & $\begin{array}{l}\text { Output, } \\
€ \text { million }\end{array}$ & $\begin{array}{l}\text { Value-added, } \\
€ \text { million }\end{array}$ & $\begin{array}{l}\text { Employment, } \\
\text { persons }\end{array}$ \\
\hline SIC103 Processing and preserving of fruit and vegetables & 472 & 135 & 1733 \\
\hline SIC105 Manufacture of dairy products & 2693 & 429 & 4692 \\
\hline SIC107 Manufacture of bakery and farinaceous products & 1095 & 473 & 8423 \\
\hline SIC108-2 Manufacture of sugar confectionery & 431 & 131 & 1576 \\
\hline SIC110 Manufacture of beverages & 1222 & 368 & 3286 \\
\hline $\begin{array}{l}\text { Total } \\
\text { \% foggregate } \\
\text { (SIC10_12Manufacture of food products and beverages) }\end{array}$ & $53 \%$ & 1535 & 19709 \\
\hline $\begin{array}{l}\% \text { of manufacturing production aggregate } \\
\text { (SIC_C Manufacturing) }\end{array}$ & 5914 & $61 \%$ & $59 \%$ \\
\hline $\begin{array}{l}\% \text { of national production aggregate } \\
\text { (SIC_0 Industries total) }\end{array}$ & $1.7 \%$ & $5.7 \%$ & $5.2 \%$ \\
\hline
\end{tabular}

Estimated direct and indirect effects on total output, value-added and employment of sugar beet production, sugar factories production and sugar utilizing industry production ( $€$ million, persons) according to the share of national production aggregate in $2011(\%)$. 


\begin{tabular}{|c|c|c|c|c|c|c|c|c|c|}
\hline & \multicolumn{3}{|l|}{$\begin{array}{l}\text { Output } \\
€ \text { million }\end{array}$} & \multicolumn{3}{|c|}{$\begin{array}{l}\text { Value-added } \\
€ \text { million }\end{array}$} & \multicolumn{3}{|c|}{$\begin{array}{l}\text { Employment } \\
\text { persons }\end{array}$} \\
\hline & Direct & Indirect & Total & Direct & Indirect & Total & Direct & Indirect & Total \\
\hline $\begin{array}{l}\text { Sugar beet } \\
\text { production }\end{array}$ & 33 & 44.6 & 77.6 & 18.2 & 13.6 & 31.8 & 800 & 296 & 1096 \\
\hline $\begin{array}{l}\text { Sugar } \\
\text { factories } \\
\text { (Säkylä, } \\
\text { Kantvik) }\end{array}$ & 165.7 & 236.7 & 402.6 & 40.6 & 77.1 & 117.7 & 245 & 485 & 730 \\
\hline $\begin{array}{l}\text { Sugar } \\
\text { utilizing } \\
\text { industry }\end{array}$ & 5914 & 8457.0 & 14371.0 & 1535 & 2916.5 & 4451.5 & 19709 & 39024 & 58733 \\
\hline Total & 6112.7 & 8258.3 & 14371.0 & 1593.8 & 2857.7 & 4451.5 & 20754 & 37979 & 58733 \\
\hline $\begin{array}{l}\% \text { of the } \\
\text { national } \\
\text { production } \\
\text { aggregate }\end{array}$ & $1.6 \%$ & $2.2 \%$ & $3.8 \%$ & $1.0 \%$ & $1.7 \%$ & $2.7 \%$ & $0.8 \%$ & $1.5 \%$ & $2.3 \%$ \\
\hline
\end{tabular}

\section{The case of NUTS3 region of Varsinais-Suomi}

The estimated direct and indirect effects ( $€$ million, persons) of the sugar chain plus the percentage share of the sugar chain's total output, value-added and employment in the NUTS3 region of Varsinais-Suomi.

\begin{tabular}{|c|c|c|c|c|c|c|c|c|c|}
\hline & \multicolumn{3}{|c|}{ Output } & \multicolumn{3}{|c|}{ Value-added } & \multicolumn{3}{|c|}{ Employment } \\
\hline & Direct & Indirect & Total & Direct & Indirect & Total & Direct & Indirect & Total \\
\hline $\begin{array}{l}\text { Sugar beet } \\
\text { production }\end{array}$ & 15.6 & 15.7 & 31.4 & 8.0 & 4.1 & 12.1 & 380 & 140 & 520 \\
\hline $\begin{array}{l}\text { Sugar } \quad \text { utilizing } \\
\text { industry }\end{array}$ & 499.3 & 549.2 & 1048.5 & 154 & 226.4 & 380.4 & 1933 & 3189 & 5122 \\
\hline $\begin{array}{lr}\begin{array}{l}\text { Sugar } \\
\text { production }\end{array} \begin{array}{r}\text { beet } \\
\text { sugd }\end{array} \\
\text { sugar utilizing } \\
\text { industry }\end{array}$ & 514.9 & 533.6 & 1048.5 & 162 & 230.5 & 392.5 & 2313 & 2809 & 5122 \\
\hline $\begin{array}{l}\% \text { of total } \\
\text { output/value- } \\
\text { added/employment } \\
\text { of NUTS3 region of } \\
\text { Varsinais-Suomi }\end{array}$ & & & $3.7 \%$ & & & $3.3 \%$ & & & $2.5 \%$ \\
\hline
\end{tabular}

\section{The case of NUTS3 region of Satakunta}

The estimated direct and indirect effects ( $€$ million, persons) of the sugar chain plus the percentage share of the sugar chain's total output, value-added and employment in the NUTS3 region of Satakunta. 


\begin{tabular}{|c|c|c|c|c|c|c|c|c|c|}
\hline & \multicolumn{3}{|l|}{ Output } & \multicolumn{3}{|c|}{ Value-added } & \multicolumn{3}{|c|}{ Employment } \\
\hline & Direct & Indirect & Total & Direct & Indirect & Total & Direct & Indirect & Total \\
\hline $\begin{array}{l}\text { Sugar factory } \\
\text { production (sugar } \\
\text { beet production } \\
\text { effects are included } \\
\text { in indirect effects) }\end{array}$ & 58.6 & 59.2 & 117.8 & 15.8 & 16.4 & 32.2 & 426 & ca. 145 & ca.571 \\
\hline $\begin{array}{l}\text { Sugar utilizing } \\
\text { industry }\end{array}$ & 274.3 & 277.0 & 551.3 & 86.3 & 89.8 & 176.1 & 1315 & 1591 & 2906 \\
\hline $\begin{array}{lr}\text { Sugar } & \text { factory } \\
\text { production } & \text { and } \\
\text { sugar } & \text { utilizing } \\
\text { industry } & \end{array}$ & 332.9 & 218.4 & 551.3 & 102.1 & 106.2 & 208.3 & 1741 & 1736 & 3477 \\
\hline $\begin{array}{l}\% \quad \text { of total } \\
\text { output/value- } \\
\text { added/employment } \\
\text { of NUTS3 region of } \\
\text { Satakunta }\end{array}$ & & & $3.5 \%$ & & & $3.5 \%$ & & & $3.4 \%$ \\
\hline
\end{tabular}

\section{Conclusions}

Information on the role of industries in the regional and national economy is important for the industries themselves in building up their public image and justifying their role in the economy. Background information on the economic role of industries is crucial to policy and decision makers due to the involvement of public financing. At the provincial and municipal level, the economic role of industries is crucial for employment and tax revenues that sustain the livelihood of the provinces and municipalities in Finland.

Even though the effects of primary sugar beet production and sugar factory production including multiplier effects seem rather small compared to the total effects at the NUTS3 regional level, the actual effects are felt at the municipalities level in the form of decreasing tax revenues and unemployment if the sugar sector in Finland disappears and is not substituted for by other forms of production and industry.

Domestic sugar production is important because of the constant supply of raw materials for the sugar utilizing industries and shield from the volatile world market prices. One good case study is from Ireland. In 2006, following the EU sugar policy reforms, Ireland's last sugar plant in Mallow was controversially closed down with a direct loss of 320 jobs. However, in 2010, a report by the European Court of Auditors found that the closure of the factory was needless because the business was profitable at the time. Since the reform of the EU sugar regime in 2006, the price of sugar eventually doubled in Ireland over the past years from about $€ 450$ to $€ 900$ per ton. The drastic increase in price for sugar and difficulty in sourcing sugar would have a profound impact on the sugar utilizing industry in Ireland. As a consequence, the Irish government is attempting to revive the Irish sugar beet industry in 2015, if it can agree an arrangement on sugar production quotas with the European Commission.

There is data to prove that without domestic production, the sugar price is higher for Ireland compared to the other EU member states due to imperfections in the EU sugar market after the reform of the EU sugar regime in 2006. The Appendix shows that the retail prices for sugar in Ireland, the UK, Finland and Germany were quite close to each other before the reform of the EU sugar regime in 2006, but the sugar prices started to diverge after 2010 with Ireland achieving the peak price without domestic sugar production and Germany maintaining the lowest price with sugar production above the self-sufficiency rate. The sugar price for consumers in Ireland is the highest compared to the United Kingdom (UK), Finland and Germany. The UK and Finland are not self-sufficient in producing sugar for the domestic market, but Germany has been always producing over its self-sufficiency limit. Therefore, the consumers in Germany enjoy the lowest price for sugar compared to Ireland, Finland 
and the UK. Due to the existing domestic sugar production in Finland and the UK, the price of sugar is lower in these countries compared to Ireland.

\section{References}

Knuuttila, M. \& Vatanen, E. 2008. Maatalouden ja metsätalouden arvonlisäysvaikutukset maakunnissa. Regional value-added effects of agriculture and forestry. Maa- ja elintarviketalous 129.

Statistic Finland 2006. Official Statistics of Finland (OSF): Regional input-output tables [e-publication]. Helsinki: Statistics Finland [referred: 20.3.2013].

Available at http://www.stat.fi/til/apt/index_en.html

Statistic Finland 2013a. Official Statistics of Finland (OSF): Annual national accounts [e-publication].

ISSN=1798-0623. Helsinki: Statistics Finland [referred: 20.3.2013].

Available at http://www.stat.fi/til/vtp/index_en.html

Statistic Finland 2013b. Official Statistics of Finland (OSF): Input-output [e-publication].

ISSN=1799-201X. Helsinki: Statistics Finland [referred: 20.3.2013].

Available at http://www.stat.fi/til/pt/index_en.html

Statistic Finland 2013c. Official Statistics of Finland (OSF): Regional and industrial statistics on manufacturing [e-publication]. Helsinki: Statistics Finland [referred: 16.4.2013].

Available at http://www.stat.fi/til/atoi/index_en.html.

Statistic Finland 2013d. Official Statistics of Finland (OSF): Regional Account [e-publication].

Helsinki: Statistics Finland [referred: 3.5.2013].

Available at http://www.stat.fi/til/altp/tau_en.html.

Taloustohtori 2013. Available at https://portal.mtt.fi/portal/page/portal/taloustohtori

\section{Appendix}

The retail price in euro for $1 \mathrm{~kg}$ of granulated white sugar in Ireland, Finland, the United Kingdom ${ }^{1}$ (UK), and Germany from 2002 to 2012

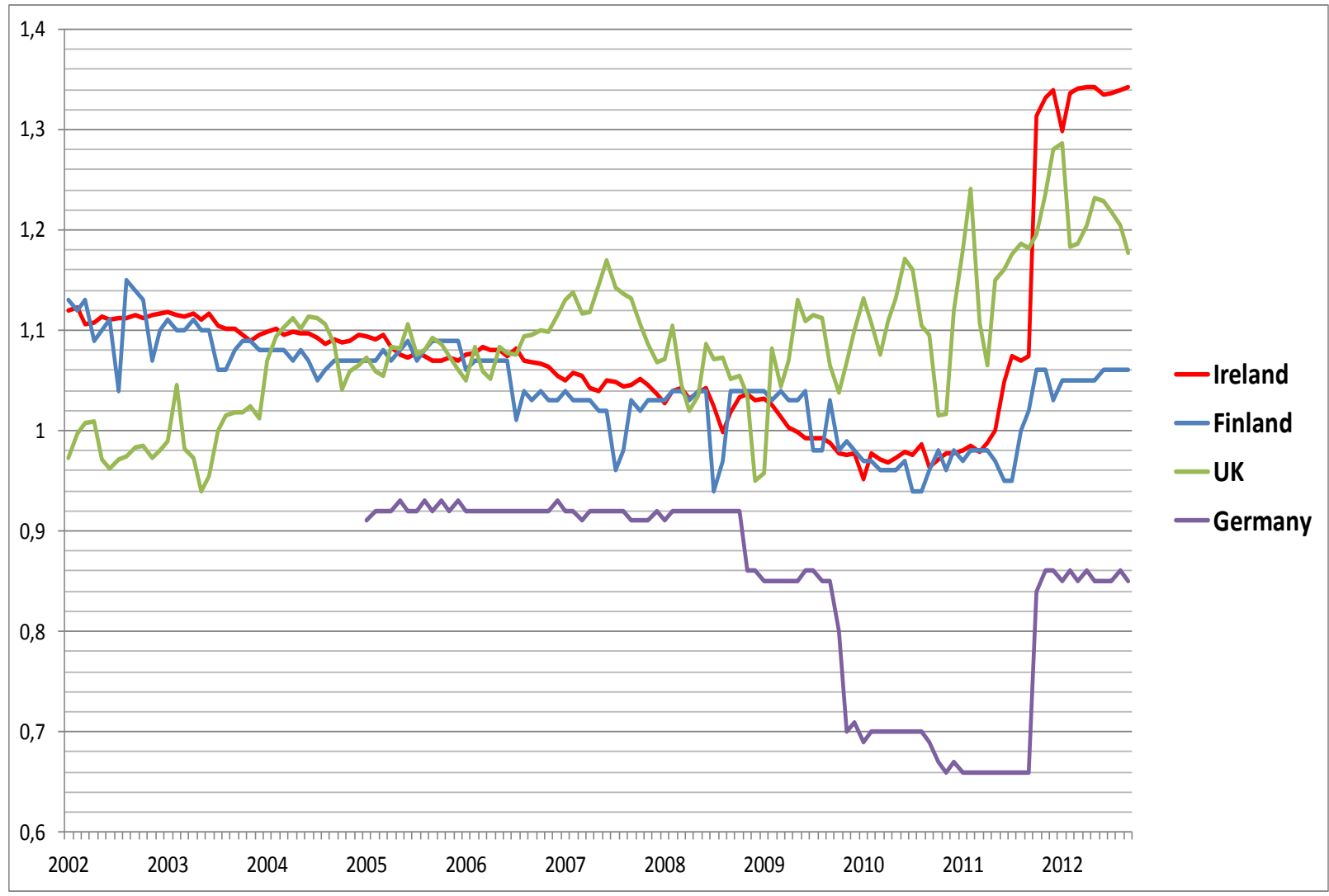

\footnotetext{
${ }^{1}$ The retail price in the UK is converted from pound to euro. Thus, the UK price is also influenced by currency fluctuation between the pound and euro.
} 